\title{
The relationship between socially responsible investment and the market value of an enterprise
}

\author{
Alexander Babkin ${ }^{1}$, Ekaterina Malevskaia-Malevich ${ }^{2}$, Nadezhda Kvasha ${ }^{3}$, and Evgenii \\ Eliseev $^{2}$ \\ ${ }^{1}$ G.P. Luzin Institute for Econimic Studies of the Kola Science of the RAS, Apatity, Russia \\ ${ }^{2}$ Peter the Great Saint-Petersburg Polytechnic University, Polytechnicheskaia 29, St. Petersburg, Russia \\ ${ }^{3}$ Bonch-Bruevich Saint-Petersburg State University of Telecommunications, St. Petersburg, Russia \\ ${ }^{2}$ Peter the Great Saint-Petersburg Polytechnic University, Polytechnicheskaia 29, St. Petersburg, Russia
}

\begin{abstract}
It is widely acknowledged, that the consequences of the coronavirus crisis have increased the impact of the concept of sustainable development on the world economy. Statistical indicators evidence this. Among other things, an obvious trend in global stock markets is the shift in the focus of institutional and individual investors from profit-oriented investment in favor of socially responsible one. Demand for all "green" products stock market is constantly growing, ahead of the proposal. This, in turn, leads to an increase in the market value of the company. It is evident that compliance with the ESG criteria creates value. The paper analyzes the influence of conscious consumption trends on the stock market. The presence of the relationship between ESG factors and the market value of the company has been substantiated. On the example of a portfolio of "green" bonds demonstrates the effect of "green halo." The main scientific problems in the area under study and the direction of further research are formulated. The potential of deliberate investment to create additional value for Russian enterprises has been determined.
\end{abstract}

\section{Introduction}

It is extremely crucial that in the modern concept of economic growth, the main role is assigned to an increase in the output of industrial products with a high level of added value. However, at the same time, the material component of production is of no less importance. The concept of sustainable development as one of the main components of the overall strategy of economic development emerged back in 1972 at the UN conference in Stockholm. The concept of a closed-loop economy or circular economy arose in the context of the need to increase resource efficiency in view of the limited nature of any, especially natural material resources.

The idea of conscious consumption, being an integral part of the sustainable development concept, has recently taken hold of the masses. Everyone puts their own meaning in this phrase, nevertheless, the basis of the concept is clear - reducing the consumption of unnecessary goods, reducing waste, sharing consumption (for example, car sharing), reuse of 
waste in production - recycling, transition to renewable energy sources, in general respectfully relationship to the world surrounding us. [1,2]

The concept has a completely conscious and justified position in view of objective reasons such as global warming, the growing garbage crisis, overpopulation of the planet, and so on, but there are also serious consequences for the economy. Conscious consumption, in fact, calls for a decrease in demand in different sectors of the economy.

"Green" economy is inextricably linked to the concept of sustainable development is an innovative model that achieves the satisfaction of the population needs, as well as improving their well-being while minimizing harmful effects on the environment. One of the main goals of sustainable development is to eliminate environmental problems that arise from climate change, depletion of natural resources and pollution, and threaten Russia's competitiveness. To date, various state strategies and programs are being implemented in order to protect the environment in accordance with the "Fundamentals of State Policy in the Field of Environmental Development of the Russian Federation for the Period up to 2030".

Ecological-oriented projects have traditionally been considered as high-risk and lowprofit and could only rely on state support. Conscious consumption has had a fundamental impact on green innovation by creating an impetus for informed investment. Conscious investment strategy involves investment of funds not only for obtaining the desired income with an acceptable level of risk, but also according to their principles and views on life. Conscious investing allows you to support socially responsible companies without giving up potential investment income. $[3,4]$

The aim of the study is to determine the role of ESG factors in the development of the market value of the enterprise, as well as identifying the prospects of "green" economy for Russian enterprises.

\section{Materials and Methods}

The theoretical basis of the research is the provisions of neoclassical and neoinstitutional economic theory; scientific principles of knowledge management and innovation; researches of scientists on the problems of innovative development of industrial economic systems of various levels. The methodological basis of the research was mainly qualitative methods, such as the method of analogies, implemented to substantiate the parameters used, as well as methods of content and expert analysis and synthesis, providing generalization of the results.

The concept of company value management (VBM) assumes the main criterion for assessing the effectiveness of its activities is the growth of the company's market value in the market. In this case, under the implied market value of index Market Cap (market capitalization), calculated as the total value of all shares outstanding. The share price on the market is set at the intersection of the supply and demand curves, and reflects the expectations of investors regarding the future of the issuing company. When choosing shares, investors traditionally relied on financial indicators of companies, such as EBITDA, P / E, Payout ratio, etc. However, the situation has changed recently. [5]

In addition to the rapid growth of technological stocks, it is worth noting another powerful trend that has developed in the stock market after the start of the COVID-19 pandemic. We are talking about a record increase in the value of assets associated with ESG criteria. ESGEnvironmental, social, governance, this is how companies are designated that meet special performance criteria: E - environmental, S - social, G - governance. [6,7]

The following figures show how important the ESG criteria are for investors today: $95 \%$ of Americans aged 25-40 (millennial generation) say that when buying shares, they take into account the social value of the chosen company. Seventy five percent of investors specify that with their investments they would like not only to earn money, but also to contribute to improving the ecology of the planet. The opinion of millennials is a barometer for the entire 
investment market - this generation will inherit assets worth about $\$ 30$ trillion from their parents in the next 10-15 years. [8,9]

Initially, the ideology of investing in ESG does not imply a rejection of profitability in favor of higher goals, however, along with the classic financial indicators of companies business marginality, revenue growth rate, profit-to-capitalization ratio - additional selection criteria appear. [10]

In the second quarter of 2021, for the first time, Time magazine published a list of the “100 Most Influential Companies of 2021". The list of nominees was compiled by polling "experts from a wide range of industries - from medicine, media and entertainment to transportation and high technology, as well as our global network of editors and correspondents. We then assessed each of the key factors such as company influence, degree of innovation, market leadership, success, and so on." [11] The list includes five categories - pioneers, leaders, innovators, titans, and foundational breakers.

Companies and services that promote new technologies to the masses or change their daily lifestyle represent the first category. There are several companies in this category whose main activity is the creation of a "green" product. These pioneers include, for example, Beyond Meat, the world's largest manufacturer of plant-based meat substitutes. [12]

In our opinion, Beyond Meat is a very interesting case that confirms the relevance of sustainable development trends in the global economy. The company produces and sells plant-based meat products.

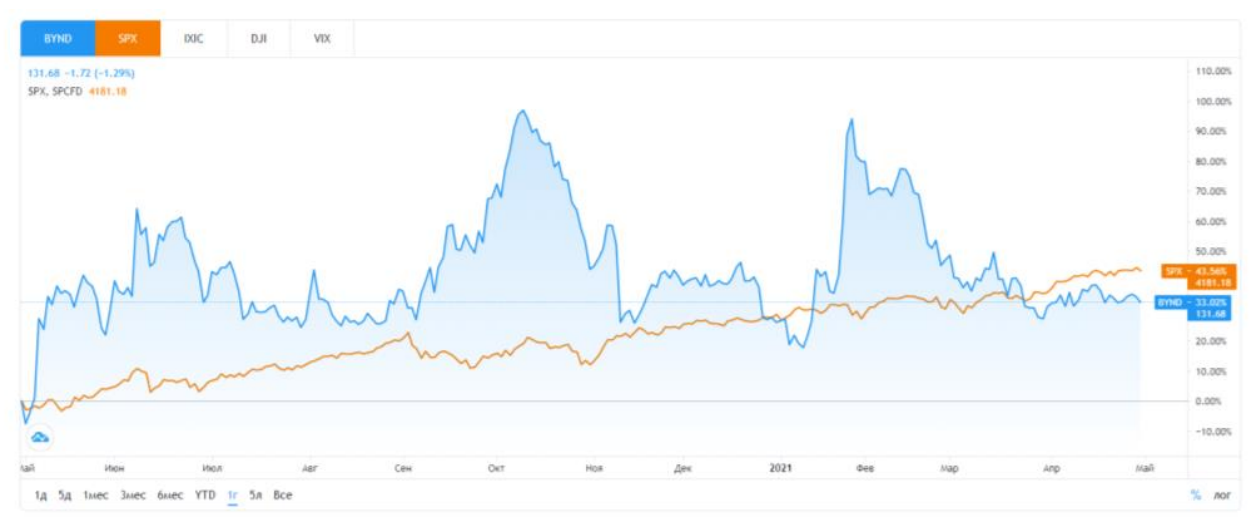

Fig. 1. Ratio of Beyond Meat stocks to S\&P 500 ETFs.

Source: https://ru.tradingview.com/symbols/NASDAQ-BYND/

The chart shows a large volatility in the share price, while it is worth noting the overall positive trend. The company's current market value is $\$ 8.41$ billion, up from $\$ 4.66$ billion in 2019, when the company went public. At the same time, the company does not pay dividends and has a negative flow from operating activities, as well as a negative net profit of -75.52 million for 2020. Obviously, a "classic" investor would not rate a company with corresponding financial indicators so highly.

According to McKinsey experts in the study "The ESG premium: new views on value and performance", companies that pay attention to the principles of responsible investing are already valued at an average of $10 \%$ more expensive than less socially responsible competitors, and in the future this factor will only grow.

The volume of funds of ESG-oriented funds and exchange-traded funds exceeded \$ 218 billion in 2020, an increase of almost 2.5 times over the previous year, the authors of the study write. Therefore, for example, the ESG fund, which repeats the usual S\&P 500 index, where environmentally harmful industries are excluded from the list, that is, "cleaned" of coal, gas and oil companies, outperforms the classic index. When you look at the top US- 
traded ESG funds, they are all ahead of the broader market. Thus, iShares ESG Aware MSCI USA ETF in the first eight months of 2020 gave $13 \%$ growth against $9.9 \%$ for the S \& P 500 . The second volume of trading in this niche iShares MSCI KLD 400 Social ETF increased by $12.7 \%$.[13]

Investors are rewriting their strategies to exclude companies from their portfolio that do not meet their Responsible Finance metrics. According to surveys by the consulting company EY, 91\% of institutional investors worldwide said that non-financial performance of companies plays a key role in their investment decisions. [14]

It is the demands of investors that have become the main motivating factor for companies' initiatives in the field of environmental sustainability, according to the Deloitte study "Climate Verification 2021: A Business View of Environmental Sustainability". [14]

\section{Results and Discussion}

Based on the results of the analysis, it can be concluded that the increased interest of investors in "green" financial products is expressed in terms of value. In the scientific literature, it is called "green premium" or "green halo", however, the conventional designations and classifications formulated by signs that characterize this particular economic phenomenon, as well as methods for assessing its effect on the moment.

Consider an example of the impact of the "green halo" on a bond portfolio. Other things being equal, green bonds are slightly more expensive for the issuer than vanilla (classic) bonds, since he must control the compliance of debt with generally accepted principles for such securities [15]. The ability to place green premium bonds could offset this difference.

Investors receive the main income from owning "green" bonds in the secondary market when they are resold, while the spread narrows even more than on the primary one, sometimes by $20-25$ basis points compared to vanilla. This can help attract "traditional" investors who invest on financial rather than environmental reasons.

In addition, NatWest Markets has found that green bonds can create a halo effect for the issuer, reducing the yield on a comparable portfolio of classic bonds.

Table 1. The "halo effect" for the issuer of "green bonds" Compare issuers spread portfolio of "green" bonds with comparable ordinary.

\begin{tabular}{|c|c|c|c|c|c|c|}
\hline \multirow{2}{*}{ Issuer } & \multirow{2}{*}{ Branch } & \multirow{2}{*}{ Country } & \multicolumn{2}{|c|}{ Green Bond portfolio } & \multirow{2}{*}{$\begin{array}{c}\begin{array}{c}\text { Duplicate } \\
\text { portfolio }\end{array} \\
\text { B.p. }\end{array}$} & \multirow{2}{*}{$\begin{array}{c}\begin{array}{c}\text { The } \\
\text { "Green } \\
\text { Halo" } \\
\text { Value }\end{array} \\
\text { B.p. }\end{array}$} \\
\hline & & & $\begin{array}{c}\text { Maturity, } \\
\text { years }\end{array}$ & $\begin{array}{c}\text { Spread, } \\
\text { b.p. }\end{array}$ & & \\
\hline $\begin{array}{c}\text { TenneT } \\
\text { Holding BV }\end{array}$ & Energy & Holland & 7.0 & 9 & 18 & 9 \\
\hline Enel SpA & Energy & Italy & 7.5 & 29 & 36 & 7 \\
\hline Engie SA & Energy & France & 7.6 & 18 & 20 & 2 \\
\hline $\begin{array}{c}\text { Unibail- } \\
\text { Rodamco SE }\end{array}$ & Real-estate & France & 7.4 & 17 & 20 & 3 \\
\hline Orsted AS & Energy & Denmark & 8.0 & 21 & 34 & 13 \\
\hline Icade & Real-estate & France & 6.5 & 39 & 41 & 2 \\
\hline $\begin{array}{c}\text { Ferrovie } \\
\text { dello Stato } \\
\text { Italian SpA }\end{array}$ & Infrastructure & Italy & 5.8 & 43 & 47 & 4 \\
\hline
\end{tabular}

* Compiled by the author based on site materials https://natwest.us/insights/articles/green-halo-20/ $(23.01 .2021)$ 
In each case, the duplicate portfolio had a wider spread. The size of the spread in the market depends on several factors, but the main factor is the liquidity of the asset, the higher the liquidity of the investment instrument, the lower the spread value. Thus, we can conclude that green bonds are liquid and less risky than similar conventional bonds. [16]. [16]

Of course, future pricing will depend on how quickly investors change their preferences. However, current price premiums could set the trend for existing green bonds to serve as a benchmark for pricing new bonds.

\section{Conclusions}

1. Based on the results of the study, the following conclusions were made: the trend of conscious consumption has an increasing impact on the economy, which must be taken into account in order to maintain the competitiveness of Russian enterprises. Considering the commodity structure of Russia's exports, where fuel and energy products traditionally account for the bulk of its exports, it can be assumed that issuing green bonds to finance green innovations in the industry will not only increase investment attractiveness for foreign investors, but also improve their business reputation.

2. In world practice, the capitalization of companies - issuers of shares that pay attention to ESG-topics, grows 3 times faster than companies that ignore the concept of sustainable development.

3. Russia is still lagging behind the global trend: more than $80 \%$ of Russian companies in the real sector do not have a sustainable development strategy, according to a survey by the Expert RA rating agency conducted in February 2021 among 150 companies. The awareness of Russian companies about ESG is extremely low.

4. Obviously, both private investors and large corporations will have to adapt to the sentiments of the younger generation investors, revising their policies in favor of the concept of sustainable development. To do this, companies will need to introduce "green" innovations, which means attracting long-term financing from sources that take into account the "green" specifics of investment.

5. Conscious consumption has initiated the trend of conscious investment - investing in green projects. To finance such projects, special financial instruments were created - "green" bonds, which have a number of features in comparison with classical ones. It has been empirically proven that "green" securities are liquid and arouse increased investor interest, despite the reduced, and sometimes even negative, profitability. Conscious investing opens up new prospects for Russian enterprises, as adherents of the concept of sustainable development are ready to invest in green instruments around the world, regardless of country or political risks.

\section{References}

1. Lasse Pedersen, Shaun Heje, Pomorski Lukasz, Journal of Financial Economics (2020)

2. Dmitriy G. Rodionov, Evgenii A. Konnikov, Magomedgusen N. Nasrutdinov, Economies, 9.2 (2021)

3. Signori, Silvana, Sustainability $\mathbf{1 3 . 3}$ (2021)

4. Jason M. Ribando, George Bonne, Thomson Reuters, 31 (2010)

5. Vilija Aleknevičienè, Inga Aleksandravičiūte, Financial Behavior of Investors: LongRun Overreaction Phenomenon in Euronext Stock Exchange (2020)

6. Vilija Aleknevičienè, Mušeikytė Gerda, Science and Studies of Accounting and Finance: Problems and Perspectives, 14.1 (2020) 
7. Investment in "moral assets" exceeded \$ 1 trillion, https://www.vedomosti.ru/

8. TIME USA, https://time.com/

9. Time has presented a list of the 100 most influential companies, https://www.kommersant.ru/

10. Investment in "moral assets" exceeded $\$ 1$ trillion, https://www.vedomosti.ru/

11. How will your company's non-financial performance affect its future? https://www.ey.com/

12. Patrik Sörqvist, Food quality and preference 43 (2015)

13. D. S. Demidenko, P. I. VaganovIOP Conference Series: Materials Science and Engineering, 940(1) (2020)

14. Caroline Harrison, Candace Partridge, Aneil Tripathy, What's in a Greenium: An Analysis of Pricing Methodologies and Discourse in the Green Bond Market (2020)

15. Dmitry Rodionov, Proceedings of the 2nd International Scientific Conference on Innovations in Digital Economy: SPBPU IDE-2020 (2020)

16. Oskar Kosch, Marek Szarucki, Journal of Business Economics and Management 21.3 (2020) 